\title{
Correlation between the ninth grade students' learning habitand reading comprehension junior high school
}

\author{
Sunan Hadi Putra ${ }^{1}$ \\ ${ }^{1}$ Sekolah Menengah Pertama Negeri 1 Tigadihaji, OKUS, Indonesia
}

\begin{tabular}{l} 
Article Info \\
\hline Article history: \\
Received Jul $12^{\text {th }}, 2021$ \\
Revised Aug $15^{\mathrm{h}}, 2021$ \\
Accepted Aug $30^{\text {th }}, 2021$ \\
\hline
\end{tabular}

\section{Keyword:}

Corelation

Learning habit

Reading comprehension

\begin{abstract}
The results of this research are expected to help the students to know themselves about their learning habits. Give information to the English teachers about students' characteristics, especially about learning. So, they can anticipate it.And also to know the students' ability in reading. This study is quantitative research with correlation research design. The correlation study is a study that involves collecting data in order to determine the degree to which a relationship exists between two or more variables. The result showed that the value of the coefficient correlation between Students' Habits (X1) and Reading Comprehension $(\mathrm{Y})$ for -0.011 . Sig. Value 0.923 was higher than Alpha value $0.05(0.923>0,2213)$.
\end{abstract}

\section{Corresponding Author:}

Putra, S. H.,

Sekolah Menengah Pertama Negeri 1 Tigadihaji, OKUS, Indonesia

Email:sunan@gmail.com

\section{Introduction}

Reading is necessary skill that any learner needs. According to [1] Reading begins with the child's mastering the names of the letters, then m,astering the letter-sound relationships, then learning some easy words in isolation, and finally reading simple stories with highly controlled vocabularies. It was assumed that the process to be a good reader is not an easy taks. [2] Reading comprehension skills is the activity where the readers are able to predict what will happen nest in a story using clue presented in text, create questions about the main idea, message, or plot of the text, and monitor understanding of the sequence, context, or characters. Learners comprehend better when they see the text organized in such a way which can easily be understood, and which indicates the relationships between ideas.

Learning reading comprehension requires a strategy where lesson plans progressively develop and reinforce reading comprehension skill, but a student does not seem to really get it by reading; this means that the student is successfully decoding words, but decoding without reading comprehension will not get him far. The interaction is important to class activity. [3] Interaction and collaboration among students complement the effective factors in foreign language learning. Self esteem, emphaty, reduced anxiety, and improved attitude and motivation are all fostered when students are engaged in genuine interaction.The learning and teaching language approach as the effort to reading comprehension focuses on the students' competence. The students are as the cornerstone of language learning. This thesis proposal examines how students in Junior high School grade can understand the English text which affect to their reading comprehension. The writer will choose the ninth grade students at SMPN 01 Tiga Dihaji OKU Selatan as the population. It is because this school is 
where the writer works as an English teacher. This study aims to know; Is there a significant correlation between Betweenthe Ninth Grade Students' Learning HabitAnd Reading Comprehension At Smpn 1 Of Tiga Dihaji, Oku Selatan. The results of this research are expacted to:

1. Help the students to know themselves about their learning habits and learning motivation.

2. Give information to the English teachers about students' characteristics, especially about learning habits and learning motivation. So, they can anticipate it.

3. Enlarge the knowledge and increase experience in doing research.

4. Give contribution to the development of English teaching learning process.

\section{Literature Review}

Successful learners must understand how their learning fits into their lives. Thay take the time to understand the type of learner they are and find ways to become even better learners.. They practice the habits of looking within themselves to build on their own strengths and weakness. They also use the learning process cycle. First, they prepare themselves by planning for the learning. Next, they have check-up during the learning. Finally at the end, they review their learning.

The first category is of the students who study for a shorter duration, have good concentration and are able to get good scores without much effort. The second category includes students who have rather poor concertration, and need a lot of haerd work to get good scores.Based on these two categories, students' learming habits background is defined. With a reguler study habit, it will be found tha the child will study at a time that is deerned normal to study, for exmple: after doing their assignments after returning from school. They generally study for a couple of hours and are least affected bby external diversions.

From the above tips to develop students' learming habits, it can be viewed that a good classification of isolated study habits will be improved when learners prefer to study late in the night or during the wee hours of the morning. Such learning habits are very good for most leaners who have low concentration span. If a learnerdoes not concentrate during class hours, the purpose of the study would be to compensate for such times instead of improving the level of understanding during study hours. Whatever students' laerning habits background, understand that these patterns can lead them into a good and effective learning habit just as they learn any other skill. dspsweb@cuesta.edu(2009) explained comprehension as the capacity for understanding fully; the act or action of grasping with the intellect. It can be assumed that reading is to understand the meaning of written or printed matter by scanning the printed letters of symbols from the texts.Identifying words on a page does not make someone a successful reader. When the words are understood and transcend the pages to become thoughts and ideas then you are truely reading. Comprehension therefore is required as the capacity for understanding those thoughts and ideas.

\section{Reading Comprehension Strategies}

Buzzle.com (2009) explained reading comprehension as the level of understanding of a passage ofr text. Reading at the rate of 200 to 220 words per minute is considered as a normal speed of reading. For normal reading rates $75 \%$ is an acceptable level of comprehension. That means if a child can understand the meaning of least $75 \%$ of the total text given then it is regarded as acceptable limits for reading comprehension.

Various methods are used to improve reading comprehension that include training the ability to self assess comprehension, actively test comprehension using a set of questions, and by improving metacognition. Practice plays more pivotal part in development and honing the skills of reading comprehension. Self assessment with help of elaborattive interrogative and summarizing helps.

\section{Purpose of Reading}

There are many purposes in reading activity. The purpose for reading will haelp the readers focus on information, consequently such purpose are most effective when establish by the reader. Obviously, the purpose for reading sould be established before a selection is read. Afterward, the stated purpose can be used as a basic for discussion to determine whether the reader has achieved hia goal. As McDonough and Shaw (1993) quoted from William that usefully classified reading into (a) Getting general information from the text, (b) Getting specific information from a text, and (c) For pleasure or interest.

From the statement above it can be concluded there are two kinds purpose of reading activity. Reading for information usually used in reading task, it is probably seen an as a type of reading ability. Readers read because they have to read. It concluded the materials which are classified as nonfiction, sciences, social 
studies, articles, newspaper, etc. Weather reading for pleasure, the reader may read either quickly or slowly based on the way he/she likes, associated largely with novel, short stories, and poems.

\section{Method}

This study is quantitative research with correlation research design, because there are three correlation among $\mathrm{X} 1, \mathrm{X} 2$ and $\mathrm{Y}$. [5] explain that quantitative research is research that the research data in the form of numeral and analysis used statistic using questionnaire, test, r-Product Moment and Multiple Regression.

The correlation study is a study that involves collecting data in order to determine the degree to which a relationship exists between two or more variables [4]. In this study, the writer use correctional study research to measure and describe the degree of relationship learning strategies, learning habits and reading comprehension. [6] population is a group of individuals who have the same characteristic. The population of the study is 140 students which some from 4 classes at SMPN 1 Tiga Dihaji, OKU Selatan. Population of this study is presented in the table of population as follow:

Table $1<$ Population of the Study>

\begin{tabular}{ccccc}
\hline No & Class & Number of Students & Total \\
1. & IX $^{1}$ & 17 & Female & 36 \\
2. & IX $^{2}$ & 17 & 19 & 34 \\
3. & IX $^{3}$ & 17 & 17 & 35 \\
4. & IX $^{4}$ & 16 & 18 & 26 \\
& TOTAL & 67 & 73 & $\mathbf{1 4 0}$ \\
\hline
\end{tabular}

Source: SMPN 01 Tiga Dihaji OKU Selatan in academic 2019/2020

The sample of this research will take purposive sampling [4]. This sample is simply study whoever is available but rather uses their judgment to select a sample that they believe, based on prior information, will provide the data they need

Table $2<$ The Sample of Study>

\begin{tabular}{ccc} 
No & Class & Total \\
1. & IX $^{1}$ & 12 \\
2. & IX $^{2}$ & 12 \\
3. & IX $^{3}$ & 12 \\
4. & IX $^{4}$ & 12 \\
& Total & 46 \\
\hline
\end{tabular}

\section{Technique for Collecting Data}

\section{Test}

In collecting the data, the writer will give the students reading comprehension test. There are 30 questions in the form of multiple choice. The aim of the test is to know the result of reading comprehension.

2. Questionnaire

In answering each question in the questionnaire which was provided by the researcher, the students rated themselves on 5 point Likert-scale.

\section{Validity Test}

Validity is the essential idea to consider when preparing or selecting an instrument for use. The kinds of validity according to [7] Content validity, a test is said to have content validity if its content constitutes a representative sample of the language skills, structures, reading, etc. In order to know if the contents of the test items given are appropriate, the writer will check the test materials to the curriculum.

\section{Reliability Test}

[4] The test is considered reliable when the reliable when the reliability coefficient of the tests will higher than 0.70 . To measure the students internal consistency (consistency among the questions) for their reliability level from the student's. Cronbach's Alpha will use in SPSS 17. 


\section{The Technique of Analyzing the Data}

In this study the writer will use r-Product Moment and Multiple Regression to apply in the data analysis with regard through the formulation of problems. This simple correlation is use to find out the correlations among three variables (independent variable and dependent variable). The first, the second and the third problems will use r-Product Moment and the fourth problems use Multiple Regression

\section{Results and Discussions}

The Data Distribution

Table 3 <The Result of Students Learning Habit (X1) Statistics>

\begin{tabular}{lrr}
\hline N & Valid & 80 \\
Mean & Missing & 0 \\
Std. Error of Mean & & 146,85 \\
Median & & 1,637 \\
Mode & & 145,00 \\
Std. Deviation & & $134^{\mathrm{a}}$ \\
Variance & & 14,644 \\
Kurtosis & & 214,458 \\
Std. Error of Kurtosis & &,- 926 \\
Range & & 532 \\
Minimum & & 59 \\
Maximum & 25 & 116 \\
Sum & 50 & 175 \\
Percentiles & 75 & 11748 \\
& & 134,25 \\
& & 145,00 \\
& & 159,75 \\
\hline
\end{tabular}

The data of learning habits were collected by using a questionnaire. The maximum score of test was 175 , the minimum score of test was 116 , and the range was 59 . The mean (or the average score) and standard deviation were 146,85 and 14,644 respectively.

Table $4<$ The Frequency Data of the Score of Learning Habits (X1)>

\begin{tabular}{ccccc}
\hline & Frequency & Percent & Valid Percent & Cumulative Percent \\
Valid & 1 & 1,3 & 1,3 & 1,3 \\
116 & 1 & 1,3 & 1,3 & 5,0 \\
118 & 2 & 2,5 & 2,5 & 6,3 \\
122 & 1 & 1,3 & 1,3 & 7,5 \\
123 & 1 & 1,3 & 1,3 & 8,8 \\
126 & 1 & 1,3 & 1,3 & 10,0 \\
127 & 1 & 1,3 & 1,3 & 15,0 \\
128 & 1 & 1,3 & 1,3 & 18,8 \\
131 & 3 & 3,8 & 3,8 & 25,0 \\
133 & 3 & 3,8 & 3,8 & 26,3 \\
134 & 5 & 6,3 & 6,3 & 28,7 \\
135 & 1 & 1,3 & 1,3 & 30,0 \\
136 & 2 & 2,5 & 2,5 & 31,3 \\
137 & 1 & 1,3 & 1,3 & 32,5 \\
138 & 1 & 1,3 & 1,3 & 37,5 \\
139 & 1 & 1,3 & 1,3 & 43,8 \\
140 & 4 & 5,0 & 5,0 & 46,3 \\
141 & 5 & 6,3 & 6,3 & 48,8 \\
142 & 2 & 2,5 & 2,5 & 51,2 \\
143 & 2 & 2,5 & 2,5 & 52,5
\end{tabular}




\begin{tabular}{ccccc}
\hline & Frequency & Percent & Valid Percent & Cumulative Percent \\
148 & 2 & 2,5 & 2,5 & 55,0 \\
151 & 2 & 2,5 & 2,5 & 57,5 \\
152 & 1 & 1,3 & 1,3 & 58,8 \\
153 & 1 & 1,3 & 1,3 & 60,0 \\
154 & 1 & 1,3 & 1,3 & 61,3 \\
155 & 3 & 3,8 & 3,8 & 65,0 \\
156 & 4 & 5,0 & 5,0 & 70,0 \\
158 & 2 & 2,5 & 2,5 & 72,5 \\
159 & 2 & 2,5 & 2,5 & 75,0 \\
160 & 3 & 3,8 & 3,8 & 78,8 \\
161 & 3 & 3,8 & 3,8 & 82,5 \\
162 & 2 & 2,5 & 2,5 & 85,0 \\
163 & 2 & 2,5 & 2,5 & 87,5 \\
166 & 3 & 3,8 & 3,8 & 91,3 \\
167 & 2 & 2,5 & 2,5 & 93,8 \\
170 & 2 & 2,5 & 2,5 & 96,3 \\
171 & 1 & 1,3 & 1,3 & 97,5 \\
175 & 2 & 2,5 & 2,5 & 100,0 \\
Total & 2,5 & 100,0 & \\
\hline
\end{tabular}

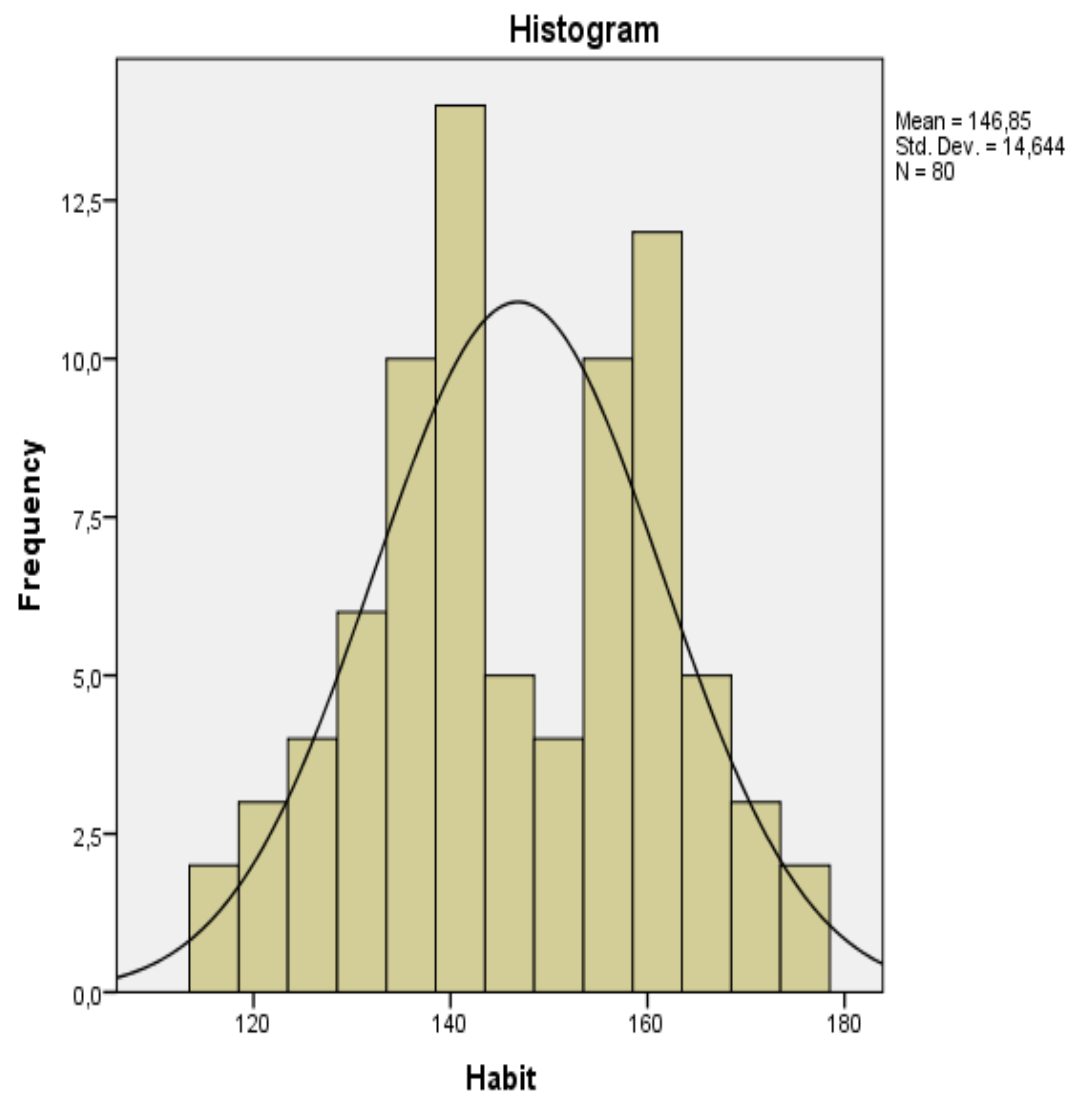

Figure $2<$ Histogram of the Score of Learning Habits $>$

The frequency data are often effectively displayed by histogram. The data from table 6 are presented as a histogram in figure 2 above. In this histogram, the vertical dimension on the graph list the frequency of the score, and the horizontal dimension rank order the score of learning Habits from the lowest to the highest. The columns are drawn in the graph to correspond with the result of the computation the data. 


\section{The Result of Students Reading Comprehension}

Table 5 <The Result of Students Reading Comprehension (Y) Statistics>

\begin{tabular}{lcc}
\hline N & Valid & 80 \\
Mean & Missing & 0 \\
Std. Error of Mean & & 23,91 \\
Median & &, 411 \\
Mode & 25,00 \\
Std. Deviation & 25 \\
Variance & & 3,677 \\
Kurtosis & & 13,524 \\
Std. Error of Kurtosis &,- 565 \\
Range & &, 532 \\
Minimum & & 13 \\
Maximum & & 17 \\
Sum & & 30 \\
Percentiles & & 1913 \\
& 25 & 21,00 \\
& 50 & 25,00 \\
\end{tabular}

The data of reading comprehension were collected by using a test. The maximum score of test was 30, the minimum score of test was 17 , and the range was 13 . The mean (or the average score) and standard deviation were 23,91 and 3,677 respectively.

Table $6<$ The Frequency Data of the Score of Reading Comprehension (Y)>

\begin{tabular}{crrrrr}
\hline & & \multicolumn{2}{c}{} & \multicolumn{2}{c}{ Cumulative } \\
Valid & Frequency & \multicolumn{2}{c}{ Percent } & Valid Percent & 10,0 \\
& 17 & 8 & 10,0 & 10,0 & 15,0 \\
19 & 4 & 5,0 & 5,0 & 28,7 \\
21 & 11 & 13,8 & 13,8 & 33,8 \\
22 & 4 & 5,0 & 5,0 & 40,0 \\
23 & 5 & 6,3 & 6,3 & 48,8 \\
24 & 7 & 8,8 & 8,8 & 65,0 \\
25 & 13 & 16,3 & 16,3 & 76,3 \\
26 & 9 & 11,3 & 11,3 & 86,3 \\
27 & 8 & 10,0 & 10,0 & 90,0 \\
28 & 3 & 3,8 & 3,8 & 100,0 \\
30 & 8 & 10,0 & 10,0 & 100,0 \\
\hline
\end{tabular}

Table above explains about the frequency of reading comprehension. Based on the table above, there were eight students who got the score 17 and the percentage was 10,0\%. There were four students who got the score 19 and the percentage was 5,0\%. There were eleven students who got the score 21 and the percentage was $13,8 \%$. There were four students who got the score 22 and the percentage was $5,0 \%$. There were five students who got the score 23 and the percentage was $6,3 \%$. There were seven students who got the score 24 and the percentage was $8,8 \%$. There were thirteen students who got the score 25 and the percentage was $16,3 \%$. There were nine students who got the score 26 and the percentage was $11,3 \%$. There were eight students who got the score 27 and the percentage was $10,0 \%$. There were three students who got the score 28 and the percentage was $3,8 \%$. There were eight students who got the score 30 and the percentage was $10,0 \%$. 


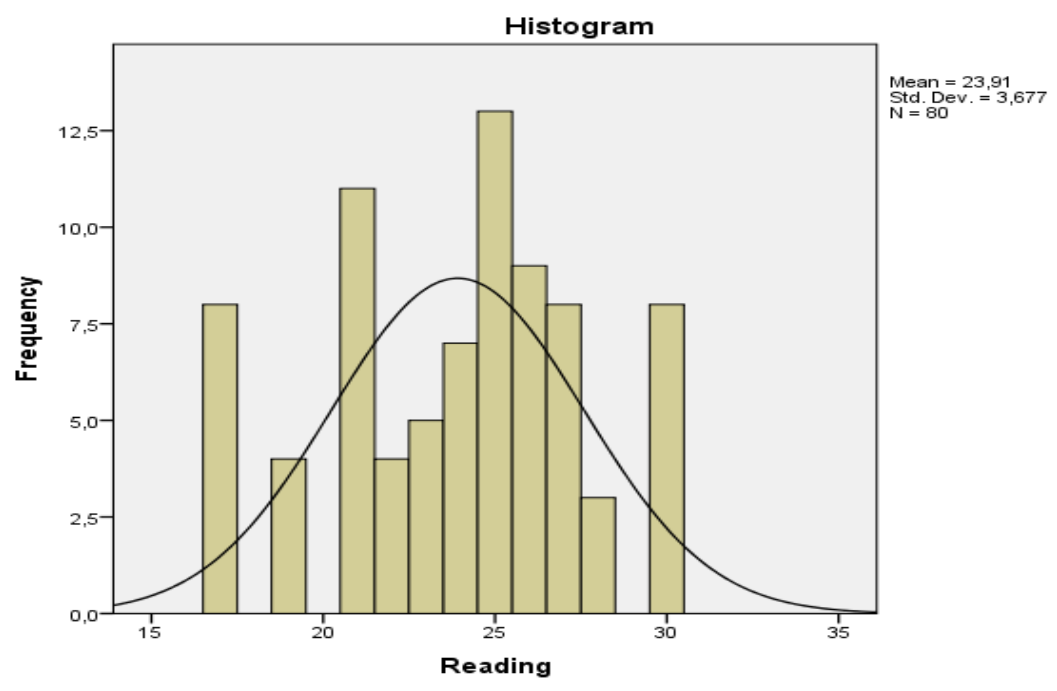

Figure $4<$ Histogram of the Score of Reading Comprehension>

\section{Correlation between Students Learning Habit $\left(\mathrm{X}_{1}\right)$ and Reading Comprehension ( $\left.\mathrm{Y}\right)$}

Table 11: Correlation between Students Learning Habit (X1) and Reading Comprehension(Y)

\begin{tabular}{cccc}
\hline Control Variables & Correlation & Habit & Reading \\
Motivation Habit & Significance (2-tailed) & 1,000 &,- 011 \\
& df &. &, 923 \\
Reading & Correlation &,- 011 & 77 \\
& &, 923 & 1,000 \\
& Significance (2-tailed) & 77 &. \\
\hline
\end{tabular}

Table above showed the value of the coefficient correlation between Students' Habit (X1) and Reading Comprehension (Y) for -0.011. Sig. Value 0.923 was higher than Alpha value $0.05(0.923>0,2213)$, Ha was rejected and Ho was accepted. In other words, there was not significant correlation between Students' Learning Habit (X1) and Reading Comprehension (Y).

\section{Statistics Formula r- Product Moment Correlation between Students Learning Habit $\left(\mathrm{X}_{1}\right)$ and Reading}

\section{Comprehension (Y)}

Table $7<$ Correlation between Students Learning Habit(X1) and Reading Comprehension (Y)>

\begin{tabular}{lcccc}
\hline Control Variables & & & Habit & Reading \\
Motivation & Habit & Correlation & 1,000 &,- 011 \\
& & Significance (2-tailed) &. &, 923 \\
& df & 0 & 77 \\
& Reading & Correlation &,- 011 & 1,000 \\
& & Significance (2-tailed) &, 923 &. \\
\hline
\end{tabular}

Table above showed the value of the coefficient correlation between Students' Habit (X1) and Reading Comprehension (Y) for $\quad-0.011$. Sig. Value 0.923 was higher than Alpha value $0.05(0.923>0,2213)$, Ha was rejected and Ho was accepted. In other words, there was not significant correlation between Students' Learning Habit (X1) and Reading Comprehension (Y). 


\section{Conclusions}

The data of learning habits were collected by using a questionnaire. The maximum score of test was 175 , the minimum score of test was 116 , and the range was 59 . The mean (or the average score) and standard deviation were 146,85 and 14,644 respectively. The results for the variable Students Learning Styles (X1) obtained coefficient $\mathrm{B}=-0.003$ and calculate the tobtained $=-0,097$ or $p$-value $=0.923$, because $0.923>0.05$. Ha was rejected, the error level $\alpha=0.05$ or $5 \%$, Ho was accepted. It can be stated that Students Learning Habits (X1) simultaneously have no significant correlated the Reading Comprehension (Y). The results for the variable Students Learning Motivation (X2) obtained coefficient B $=-0.031$ and calculate the tobtained $=-0,462$ or $p$ value $=0.645$, because $0.645>0.05$. Ho was accepted, the error level $\alpha=0.05$ or $5 \%$, Ha was rejected. It can be stated that Students Learning Motivation (X2) simultaneously have no significant correlated the Reading Comprehension $(\mathrm{Y})$

\section{References}

Harp, Bill \& Brewer, Jo Ann (1996). The Informed Reading Teacher: Research-Based Practice. University of Massachusetts Lowell: Pearson.

Sanders, M. (2001).Understanding Dyslexia and the Reading Process: A Guide for Educators and Parents. Needham Heights, MA: Allyn and Bacon

Shumin, Kang. (1997). Factors to Consider: Ceveloping Adult EFL Students' Speaking Abilities in Richards, Jack C. and Renandya, Willy A. (eds.). 2002. Methodolgy in Language Teaching :a Anthology of Current Practice.Cambrige: Cambrige University Press.

Fraenkel, Jack. R., and Norman E. Wallen. (2012). How to Design and Evaluate Research in Education 8thEdition. Boston: McGraw-Hill Higher Education.

Sugiyono. 2012. Metode Penelitian Kuantitatif Kualitatif dan R\&B. Bandung: Alfabeta.

Creswell, J. W. (2005). Educational research: Planning, conducting, and evaluating quantitative and qualitative research. Upper Saddle River, NJ: Pearson Education.

Hughes, A. 1989: Testing for language teachers. Cambridge and New York: Cambridge University Press ix + 172 pp. ISBN 0-521-27260-2 